\title{
Optimalisasi Pemberdayaan Narapidana Lembaga Permasyarakatan Terbuka Melalui Literasi Keuangan
}

\section{The Optimalization of Empowerment to Convicted Criminal in the Open Prison through Financial Literacy}

\author{
${ }^{1}$ Nina Farliana, ${ }^{1}$ Khasan Setiaji, ${ }^{1}$ Indri Murniawaty, ${ }^{2}$ Hanif Hardianto \\ 1 Jurusan Pendidkan Ekonomi, Fakultas Ekonomi, Universitas Negeri Semarang \\ 2 Program Pascasarjana Magister Ilmu Hukum, Universitas Diponegoro, Semarang \\ Korespondensi: Nina Farliana, ninafarliana@mail.unnes.ac.id
}

Naskah Diterima: 11 September 2019. Disetujui: 21 Januari 2020. Disetujui Publikasi: 22 Januari 2020

\begin{abstract}
One of the empowerment of convicted criminals is done by increasing financial literacy. The aims of community service are: empowering convicted criminals class II B Kendal open prison through training financial management system, and give positive contribution by training financial management systems to improve financial literacy. The method of implementing community service activities is carried out by: coordination and mapping needs in prisons, focus group discussions (FGD) and financial literacy workshops, as well as post workshop assistance. The strategic steps of service are: convicted criminals in the prison class II B Kendal is given knowledge about financial literacy, convicted criminals are given training and understanding to develop financial literacy through financial management training, discussion sessions, questions and answers by giving opportunities to convicted criminals and prison management related to financial literacy, simulations implementation of financial literacy through personal and family financial management, as well as assisting and monitoring implementation financial literacy, and evaluating the results of service activities that have been carried out. Convicted criminals the prison class II B Kendal are dominated by elementary and junior high school graduates, who commit violations of the law due to economic needs. This community service program is a solution to overcome the low financial literacy of fostered citizens. The success of this service program is due to the achievement of target participants as well as the achievement of objectives and activity material. People who have good financial literacy are able to make the right decisions in financial management in order to face global challenges based on technological progress.
\end{abstract}

Keywords: Empowerment, convicted criminal, financial literacy.

\begin{abstract}
Abstrak. Pemberdayaan narapidana salah satunya dilakukan dengan peningkatan literasi keuangan. Tujuan kegiatan pengabdian ini adalah memberdayakan narapidana lembaga permasyarakatan terbuka kelas II B Kendal melalui pelatihan sistem pengelolaan keuangan, serta memberikan kontribusi positif dengan adanya pelatihan sistem pengelolaan keuangan untuk meningkatkan literasi keuangan. Metode pelaksanaan kegiatan pengabdian dilakukan dengan: koordinasi dan pemetaan kebutuhan di lapas, focus group discussion (FGD) dan workshop literasi keuangan, serta pendampingan pasca workshop. Langkah strategis pengabdian yaitu: narapidana lapas terbuka kelas II B Kendal diberikan pengetahuan tentang literasi keuangan, narapidana diberikan pelatihan dan pemahaman untuk mengembangkan literasi keuangan melalui pelatihan pengelolaan keuangan, yaitu pencatatan keuangan, sesi diskusi dan tanya jawab dengan memberikan kesempatan kepada narapidana dan pengelola lembaga permasyarakatan terkait literasi keuangan, simulasi implementasi literasi keuangan
\end{abstract}


melalui pengelolaan keuangan pribadi dan keluarga, serta melakukan pendampingan dan monitoring kepada narapidana dalam pengimplementasian literasi keuangan, terakhir melakukan evaluasi hasil kegiatan pengabdian yang telah dilakukan. Warga binaan Lapas Terbuka Kelas II B Kendal didominasi oleh lulusan SD dan SMP, yang melakukan pelanggaran hukum karena dorongan kebutuhan ekonomi. Program pengabdian kepada masyarakat ini sebagai solusi mengatasi rendahnya literasi keuangan warga binaan. Keberhasilan program pengabdian ini karena ketercapaian target peserta serta ketercapaian tujuan dan materi kegiatan. Masyarakat yang memiliki literasi keuangan yang baik mampu membuat keputusan yang tepat dalam pengelolaan keuangannya guna menghadapi tantangan global yang berbasis kemajuan teknologi.

Kata kunci: Pemberdayaan, narapidana, literasi keuangan

\section{Pendahuluan}

Narapidana adalah terpidana yang menjalani pidana di Lembaga Pemasyarakatan (Undang-Undang Republik Indonesia No.12 Th.1995 tentang Pemasyarakatan, n.d.). Lembaga Pemasyarakatan adalah tempat untuk melaksanakan pembinaan terhadap narapidana dan anak didik pemasyarakatan (Undang-Undang Republik Indonesia No.12 Th.1995 tentang Pemasyarakatan, n.d.). Berbagai permasalahan dialami narapidana dalam menjalani kehidupan di lembaga pemasyarakatan, diantaranya perubahan hidup, hilangnya kebebasan dan hak-hak yang semakin terbatas, hingga perolehan label panjahat yang melekat pada dirinya serta kehidupan di lembaga pemasyarakatan membuat mereka harus terpisah dari keluarga dan hidup bersama narapidana lain.

Kehidupan seorang narapidana lembaga pemasyarakatan tentunya berbeda dengan kehidupan seseorang yang tinggal di luar lembaga pemasyarakatan. Mereka tidak dapat merasakan kebebasan seperti kehidupan di luar lembaga pemasyarakatan. Pemenjaraan yang terjadi pada narapidana seringkali muncul adanya rasa rendah diri dan kontak-kontak yang minim dengan dunia luar (Kartono, 2011). Kondisi tersebut mengakibatkan para narapidana sukar untuk diterimakembali di tengah-tengah masyarakat ketika nantinya mereka bebas. Seseorang yang pernah berstatus menjadi seorang narapidana juga berdampak pada sulitnya mendapatkan kepercayaan dari masyarakat dan sulit dipercaya untuk diberi tanggung jawab, sehingga sulit bagi para narapidana mendapatkan pekerjaan setelah mereka keluar dari hukuman penjaranya.

Narapidana pada hakikatnya adalah manusia yang kehilangan kemerdekaannya dikarenakan adanya pelanggaran hukum. Narapidana memiliki hak yang sama seperti warga negara pada umumnya, baik dalam bidang pendidikan, sosial, budaya dan politik, dimana narapidana juga berperan dalam meningkatkan pertumbuhan ekonomi, baik di dalam lembaga permasyarakatan (lapas) maupun setelah keluar dari lapas. Salah satu kesamaan hak yang dimiliki narapidana adalah mendapatkan pendidikan yang bermutu dan berkualitas. Pendidikan yang diperoleh narapidana di lembaga permasyarakatan yang dalam hal ini adalah pendidikan luar sekolah dilaksanakan untuk melengkapi pengetahuan dan keterampilan yang kurang atau tidak dapat diperoleh di pendidikan sekolah.

Kartono (2011) \& Sholichatun (2011) mengatakan bahwa narapidana dalam proses penahanan mengalami kesulitan dan masalah seperti, konflik batin, trauma, gangguan kepribadian, penyimpangan seksual, menutup diri, emosi yang tidak stabil, kecemasan, mudah curiga, kesulitan beradaptasi, kejenuhan akan rutinitas kegiatan dan makanan, kerinduan kepada keluarga, tidak siap menghadapi realitas, masalah dengan teman dan kecemasan akan masa depan setelah keluar dari lapas, bunuh diri, kehilangan rasa kepercayaan diri bahkan bisa melakukan tindak kejahatan yang jauh lebih buruk dari sebelumnya. Selain itu, persepsi masyarakat tentang narapidana dapat memberikan efek buruk mengenai diri mereka. 
Lembaga pemasyarakatan membuat individu yang awalnya memiliki kebebasan menjadi individu yang terbatas dalam banyak hal. Keterbatasan tersebut berkaitan dengan adanya aturan-aturan yang harus dipatuhi, kehilangan privasi, dan juga terpisah dari dunia luar, seperti keluarga dan teman (Bull, et al., 2006). Salah satu lembaga permasyarakatan di kabupaten Kendal adalah lembaga permasyarakatan terbuka kelas II B berlokasi di desa Wonosari, Kecamatan Patebon Kabupaten Kendal. Lembaga permasyarakatan terbuka kelas II B Kendal berdiri di atas tanah sekitar 7,5 hektare yang terdiri dari lahan pertanian, peternakan, dan perikanan, diresmikan Menteri Hukum dan HAM (Menkumham) Yasonna H. Laoly pada Sabtu, 29 April 2017 dan dinamai Lapas Produktif.

Pendirian Lapas Produktif seiring dengan pergeseran paradigma tentang lembaga pemasyarakatan tidak sekadar memberi keterampilan sebagai bekal warga binaan, tetapi juga mengarahkan pembinaan yang produktif dalam mewujudkan pembangunan industri dalam lapas serta mempersiapkan tenaga terampil, khususnya bagi mantan narapidana, sehingga dan siap bekerja pada saat bebas nanti. Lapas tidak hanya menjadi tempat pembinaan narapidana secara konvensional, tetapi juga dapat menjadi salah satu sarana untuk mendorong dihasilkannya produk-produk berkualitas. Oleh karena itu, kegiatan produktif di lapas bisa menjadi penunjang bagi pembinaan terhadap warga binaan pemasyarakatan. Data jumlah narapidana di Lembaga Permasyarakatan Terbuka kelas II B Kendal dipaparkan pada tabel 1.

Tabel 1. Jumlah Narapidana Lembaga Permasyarakatan Terbuka Kelas II B Kendal Tahun 2014-2019

\begin{tabular}{llcccccr}
\hline No & Periode & 2014 & 2015 & 2016 & 2017 & 2018 & 2019 \\
\hline 1 & Januari & 5 & 15 & 6 & 7 & 7 & 40 \\
2 & Februari & 5 & 3 & 4 & 17 & 17 & 34 \\
3 & Maret & 5 & 4 & 16 & 11 & 11 & \\
4 & April & 5 & 2 & 14 & 27 & 27 & \\
5 & Mei & 4 & 8 & 8 & 22 & 22 & \\
6 & Juni & 4 & 8 & 9 & 10 & 10 & \\
7 & Juli & 4 & 5 & 3 & 13 & 13 & \\
8 & Agustus & 4 & 0 & 1 & 16 & 16 & \\
9 & September & 4 & 5 & 4 & 8 & 8 & \\
10 & Oktober & 13 & 4 & 12 & 10 & 10 & \\
11 & November & 9 & 7 & 17 & 13 & 13 & \\
12 & Desember & 21 & 3 & 14 & 9 & 9 & \\
\hline
\end{tabular}

Sumber: http://smslap.ditjenpas.go.id

Berdasarkan data Direktorat Jenderal Pemasyarakatan tahun 2019 pada Tabel 1, jumlah narapidana per Februari 2019 berjumlah 34 orang merupakan napi dewasa laki-laki. Mereka memiliki latar belakang kasus yang berbeda-beda. Berdasarkan hasil observasi dan wawancara dengan kepala bidang pembinaan Lapas Terbuka kelas IIB Kendal, sebagian besar narapidana melakukan tindakan yang melanggar hukum karena dorongan kebutuhan ekonomi yaitu tidak memiliki pekerjaan tetap, penghasilan yang pas-pas dan bahkan tidak cukup untuk memenuhi kebutuhan hidup, terlalu banyak beban hutang, dan lain sebagainya. Berdasarkan masalah tersebut, akhirnya masyarakat melakukan tindakan penipuan, pencurian, perampokan, pembunuhan serta asusila, yang berimbas kepada kasus pelanggaran hukum dan mendapat predikat narapidana. Keterbatasan pengetahuan ekonomi yang dimiliki masyarakat mengakibatkan mereka melakukan tindakan negatif yang merugikan, tidak hanya bagi diri sendiri tetapi juga masyarakat. 
Rendahnya pendidikan yang dimiliki masyarakat menjadikan mereka tidak mampu mengelola keuangan dengan baik. Disisi lain, mereka tetap harus memenuhi kebutuhan mereka dan keluarga untuk tetap bisa bertahan hidup. Khrisna (2010) menjelaskan kesulitan keuangan bukan hanya fungsi dari pendapatan semata (rendahnya pendapatan). Kesulitan keuangan juga dapat muncul jika terjadi kesalahan dalam pengelolaan keuangan (miss-management) seperti kesalahan penggunaan kartu kredit, dan tidak adanya perencanaan keuangan. Keterbatasan finansial dapat menyebabkan stress, dan rendahnya kepercayaan diri. Pengetahuan tentang keuangan yang kurang akan mengakibatkan kerugian bagi individu, atau berkembangnya sistem perekonomian yang menjadikan masyarakat lebih konsumtif atau lebih menjadi boros (Margaretha \& Pambudhi, 2015). Oleh karena itu, berdasarkan latar permasalahan tindakan pelanggaran hukum yang dilakukan narapidana diperlukan program pembinaan khusus untuk mempersiapkan narapidana pasca keluar dari lapas sehingga dapat memenuhi kebutuhan ekonomi yaitu melalui keterampilan pengelolaan keuangan atau yang dimaksud dengan literasi keuangan.

Laily (2016) mengemukakan bahwa literasi keuangan didefinisikan sebagai kecerdasan atau kemampuan seseorang dalam mengelola keuangannya. Literasi keuangan merupakan suatu keharusan bagi tiap individu agar terhindar dari masalah keuangan karena individu seringkali dihadapkan pada trade off yaitu situasi dimana seseorang harus mengorbankan salah satu kepentingan demi kepentingan lainnya. Masalah trade off terjadi karena seseorang dibatasi oleh kemampuan finansialnya (pendapatan) untuk memperoleh semua barang yang diinginkan. Literasi keuangan mempengaruhi hampir semua aspek yang berhubungan dengan perencanaan dan pengeluaran uang seperti pendapatan, penggunaan kartu kredit, tabungan, investasi, manajemen keuangan dan pembuatan keputusan keuangan.

Menurut Tomášková et al., (2011) dijelaskan bahwa literasi keuangan adalah sebuah sistem pengetahuan keterampilan, dan sikap yang penting untuk mengamankan keuangan itu sendiri dan keluarga di dalam masyarakat kontemporer. Masyarakat yang memiliki budaya literasi keuangan dapat mengelola dengan baik adanya isu uang dan harga, dan dapat mengatur dengan baik anggaran keuangan keluarga maupun pribadi, termasuk manajemen aset keuangan dan utang dengan tujuan untuk merubah kehidupan. Lusardi, et al., (2010) mengemukakan bahwa seseorang dengan pemahaman literasi keuangan yang tinggi memiliki kehidupan ekonomi yang lebih baik sehingga memudahkan pengambilan keputusan keuangannya.

Keputusan keuangan yang diambil oleh seorang individu meliputi berapa jumlah uang yang harus dikonsumsi tiap periode, apakah ada kelebihan dan bagaimana kelebihan tersebut diinvestasikan serta bagaimana mendanai investasi dan konsumsi (Widayati, 2012). Lebih lanjut, Chinen (2012) mengatakan bahwa individu yang memiliki kemampuan untuk membuat keputusan yang benar tentang keuangan tidak akan memiliki masalah keuangan dimasa depan dan menunjukkan perilaku keuangan yang sehat serta mampu menentukan prioritas kebutuhan bukan keinginan. Perilaku keuangan yang sehat ditunjukkan oleh aktivitas perencanaan, pengelolaan serta pengendalian keuangan yang baik. Indikator perilaku keuangan yang baik dapat dilihat dari cara/sikap seseorang dalam mengelola keluar masuknya uang, manajemen kredit, tabungan dan investasi (Hilgert, 2003). Bijak tidaknya pengelolaan keuangan pribadi ini erat kaitannya dengan literasi keuangan.

Konsep pemberdayaan narapidana lembaga permasyarakatan terbuka kelas II B Kendal melalui literasi keuangan yang dimaksud disini adalah pemberian teori dan konsep dasar literasi keuangan disertai pelatihan keterampilan dan simulasi 
pengelolaan keuangan yang baik dan benar, sehingga meningkatkan kemandirian dan kecermatan narapidana dalam mengelola keuangan pribadi maupun keuangan usaha. Selain itu juga membiasakan narapidana untuk berperilaku ekonomi melalui pengaturan keuangan, sehingga diharapkan tidak terjadi lagi kesalahan yang akan mengakibatkan terjadinya pelanggaran hukum.

Bentuk permasalahan yang dihadapi secara umum adalah: minimnya pengetahuan pengelolaan keuangan yang dimiliki narapidana, minimnya sarana dan prasarana dalam pengembangan keterampilan, rendahnya tingkat pendidikan narapidana, kurangnya kepercayaan diri narapidana, karena takut akan tidak terima kembali di tengah-tengah masyarakat pasca bebas dari lembaga permasyarakatan, serta kurangnya kesiapan dalam perencanaan hidup menghadapi masa akhir tahanan. Dari beberapa permasalahan yang dipaparkan, maka perlu dilakukan pengabdian masyarakat tentang pelatihan pengelolaan keuangan untuk meningkatkan literasi keuangan narapidana.

Tujuan kegiatan pengabdian kepada masyarakat adalah memberdayakan narapidana lembaga permasyarakatan terbuka kelas II B Kendal melalui pelatihan sistem pengelolaan keuangan untuk meningkatkan literasi keuangan, serta memberikan kontribusi positif dengan adanya pelatihan sistem pengelolaan keuangan untuk meningkatkan literasi keuangan bagi narapidana di lembaga permasyarakatan terbuka kelas II B Kendal. Manfaat yang dapat diperoleh dari kegiatan ini adalah memberdayakan narapidana untuk dapat mengembangkan keterampilan dan keahlian melalui pelatihan pengelolaan keuangan untuk meningkatkan literasi keuangan masyarakat. Pelatihan sistem pengelolaan keuangan bagi narapidana ini diharapkan dapat meningkatkan kemandirian serta kecermatan narapidana dalam mengatur keuangan, baik keuangan pribadi, keluarga maupun keuangan usaha. Selain itu juga meningkatkan kesadaran masyarakat tentang pentingnya memahami literasi keuangan.

\section{Metode Pelaksanaan}

Tempat dan Waktu. Program pengabdian masyarakat ini dilakukan di lembaga permasyarakatan terbuka kelas II B Kendal yang beralamat di Jalan Raya BlederKendal Km. 10, Kecamatan Patebon Kabupaten Kendal, selama 8 bulan mulai bulan April sampai November 2019. Tempat kegiatan program pengabdian masyarakat berjarak $44 \mathrm{Km}$ dari Universitas Negeri Semarang.

Khalayak Sasaran. Khalayak sasaran program pengabdian masyarakat ini adalah narapidana dan pegawai lembaga permasyarakatan terbuka kelas II B Kendal. Jumah peserta 34 narapidana dan 30 pegawai lembaga permasyarakatan terbuka kelas II B Kendal. Partisipasi mitra dilakukan dengan cara mengikuti pelatihan, pendampingan dan memahami paparan materi terkait konsep literasi keuangan, kemudian dilanjutkan dengan terlibat dalam simulasi pengelolaan keuangan yang akuntabel.

Metode Pengabdian. Kegiatan pengabdian kepada masyarakat berupa pemberdayaan narapidana melalui peningkatan literasi keuangan dan pelatihan pengelolaan keuangan yang akuntabel yang dilakukan dengan: koordinasi dan pemetaan kebutuhan di lapas, focus group discussion (FGD) dan workshop literasi keuangan, serta pendampingan pasca workshop. Adapun langkah-langkah strategis yang pengabdi rumuskan dijelaskan dalam flowchart gambar 1 .

Indikator Keberhasilan. Kegiatan pengabdian kepada masyarakat ini dikatakan berhasil jika: semua metode pengabdian telah dilakukan, ada peningkatan kesadaran masyarakat tentang literasi keuangan sebesar 80\% dari total semua narapidana, perubahan sikap dan selektifitas dalam memilih produk-produk keuangan, serta kemandirian dan kecermatan dalam mengelola keuangan, baik keuangan pribadi, keluarga maupun keuangan usaha.

Jurnal Panrita Abdi, 2020, Volume 4, Issue 1.

http://journal.unhas.ac.id/index.php/panritaabdi 
Metode Evaluasi. Evaluasi kegiatan pengabdian kepada masyarakat dilakukan dengan cara monitoring berkala dan observasi serta wawancara ketercapaian program. Memantau perkembangan pemahamaan pengelolaan keuangan warga binaan, dengan harapan akan ada peningkatan kesadaran dalam mengelola keuangan.

Langkah 1 :

Koordinasi dan pemetaan kebutuhan di lembaga pemasyarakatan terbuka kelas II B Kendal
Langkah 2 :

Narapidana lapas terbuka kelas II B

Kendal diberikan pelatihan dan pemahaman untuk mengembangkan literasi keuangan melalui pelatihan pengelolaan keuangan, yaitu pencatatan
Langkah 4 :

Workshop implementasi literasi keuangan melalui pengelolaan keuangan pribadi dan keluarga

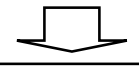

Langkah 3 :

focus group discussion (FGD), yaitu diskusi dan tanya jawab dengan memberikan kesempatan kepada narapidana dan pengelola lapas terkait

Langkah 5 :

Melakukan pendampingan dan monitoring kepada narapidana dalam pengimplementasian literasi keuangan

Gambar 1. Langkah Strategis Pemberdayaan Narapidana Lembaga Permasyarakatan Terbuka Kendal Melalui Literasi Keuangan

\section{Hasil dan Pembahasan}

\section{A. Koordinasi dan Pemetaan Kebutuhan di Lapas}

Kegiatan koordinasi awal dilaksanakan di kantor lembaga permasyarakatan terbuka kelas IIB Kendal yang beralamat di Jalan Raya Bleder-Kendal Km. 10, Kecamatan Patebon Kabupaten Kendal dengan Kepala Bagian Pembinaan Lapas yaitu Bapak Joned pada hari Sabtu tanggal 23 Februari 2019. Hasil obersevasi dan koordinasi meliputi: (1) kondisi warga binaan yang semuanya berjenis kelamin lakilaki sejumlah 45 per Februari 2019, dan berusia sekitar 18 sampai 45 tahun. Warga binaan tersebut semuanya berasal dari keluarga menengah kebawah, sehingga secara ekonomi dan psikologis juga berbeda satu sama lain. (2) Pegawai lapas terbuka kelas IIB Kendal sejumlah 45 orang, dan hampir sebagian besar merupakan lulusan SMA yang baru keterima CPNS 2018, sehingga secara akademis dan keterampilan masih kurang berpengalaman. (3) Lapas terbuka kelas IIB Kendal diperuntukkan untuk warga binaan yang akan keluar dari lapas dalam kurun waktu 1 sampai 2 tahun melalui pembinaan bidang pertanian, peternakan, perikanan dan jasa perbengkelan.

Menindaklanjuti observasi dan koordinasi awal pada tanggal 23 Februari 2019, kemudian pada hari Senin tanggal 11 Maret 2019 dilakukkan koordinasi kedua dengan kepala Lapas Terbuka kelas IIB Kendal Bapak Sutarno, Bclp., SH., MH. Hasil koordinasi kedua meliputi: (1) Hal yang dibutuhkan oleh warga binaan dan pegawai lapas adalah berupa pelatihan keterampilan, terutama optimalisasi 
pengelolaan keuangan, baik keuangan individu, keluarga maupun usaha yang bisa dimanfaatkan dan dikembangkan secara berkelanjutan sehingga bisa meningkatkan literasi keuangan warga binaan dan pegawai lapas. (2) Perlu adanya kerjasama antara akademisi dan praktisi, dalam hal ini adalah pihak Universitas Negeri Semarang dengan Lembaga Permasyarakatan Terbuka Kelas IIB Kendal. Kerjasama yang bisa dilakukan diantaranya adanya pelatihan keterampilan bidang ekonomi dan keuangan. Kerjasama ini dirasa penting untuk sebagai bentuk tanggungjawab sosial dan kepedulian terhadap warga binaan yang tidak lain adalah bagian dari warga negara Indonesia.

Koordinasi kedua yang dilakukan dengan kepala Lapas Terbuka kelas IIB Kendal menghasilkan memorandum of agreement (MoA) dengan nomor MoA W13.PAS.PAS 5.HH.05.05- dan Nomor: 3900/UN37.1.7/KS/2019. MoA tersebut sebagai bentuk perjanjian kerjasama antara Universitas Negeri Semarang yang dalam hal ini adalah Fakultas Ekonomi dengan Lembaga Permasyarakatan Terbuka Kelas IIB Kendal. Isi dari MoA tersebut adalah adanya kesepakatan untuk melakukan kegiatan pembekalan dan pengembangan diri bagi warga binaan dan pegawai atau pengelola lembaga permasyarakatan, sehingga mereka memiliki keterampilan khusus sebagai bekal ketika telah keluar dari lembaga permasyarakatan.

\section{B. Focus Group Discussion (FGD) dan Workshop Literasi Keuangan}

Hasil kegiatan yang merupakan program pengabdian tahap selanjutnya adalah focus group discussion (FGD) dan workshop literasi keuangan bagi warga binaan dan pegawai lapas. Kegiatan ini dilakukan pada hari Kamis, 18 Juli 2019. Hal ini dilakukan mengingat kesepakatan dan kesesuaian jadwal tim pengabdi dengan kepala bagian pembinaan lapas terbuka kelas IIB Kendal. Kegiatan diselenggarakan mulai pukul 08.00 WIB sampai dengan pukul 13.00 WIB, di gedung serbaguna kawasan pembinaan lapas produktif dan dibuka langsung oleh kepala Lembaga Permasyarakatan Terbuka Kelas IIB Kendal (Gambar 1). Kegiatan ini dihadiri oleh tim pengabdian kepada masyarakat fakultas ekonomi dan pegawai lapas terbuka kelas IIB Kendal serta warga binaan. Total peserta 60 orang.

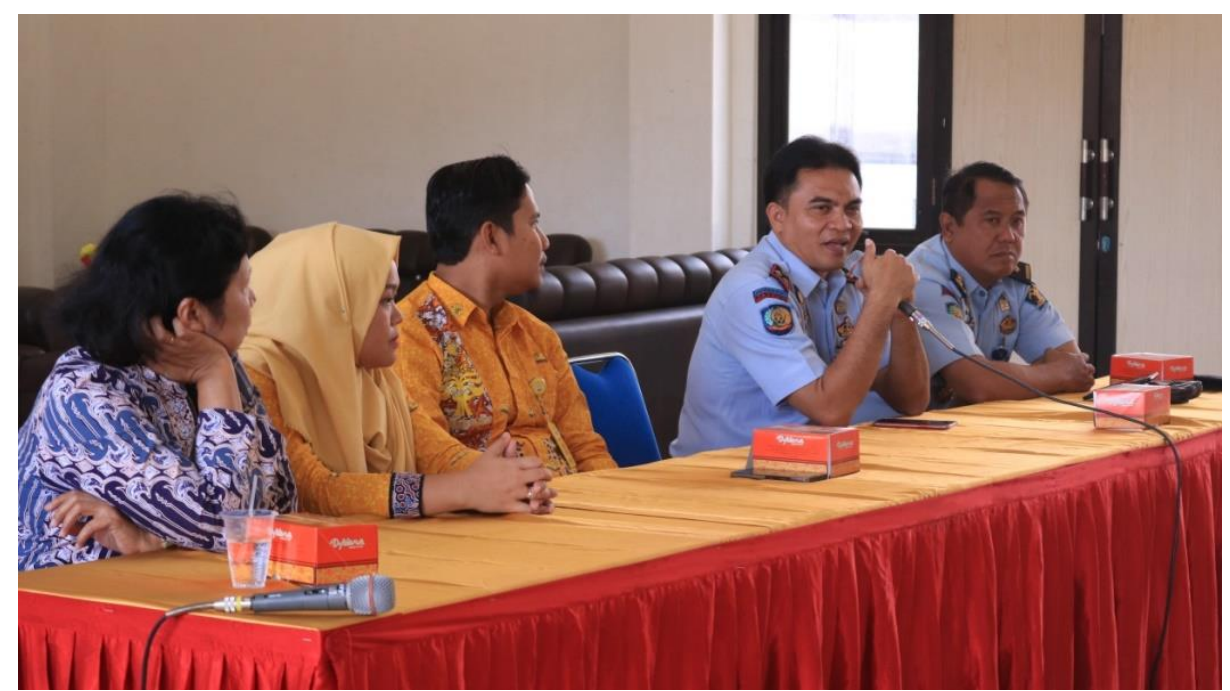

Gambar 2. Sambutan Kepala Lapas Terbuka Kelas IIB Kendal

Kepala lapas terbuka kelas IIB Kendal dalam sambutannya menyampaikan untuk lebih mampu meningkatkan literasi keuangan seiring dengan target kinerja Kementerian Hukum dan HAM dalam melakukan pembinaan kepada warga binaan. Ketua tim pengabdi masyarakat Fakultas Ekonomi Universitas Negeri Semarang 
melalui sambutannya juga berharap kegiatan ini bisa memberikan kontribusi dan motivasi bagi pegawai dan terutama bagi warga binaan permasyarakatan, agar mampu merubah pola pikir dalam memahami pengelolaan keuangan serta mampu meningkatkan keterampilan dibidang ekonomi.

Kegiatan inti focus group discussion (FGD) dan workshop disampaikan oleh narasumber yang kompeten dibidang pengembangan sumber daya alam dan digitalisasi produk. Narasumber pertama adalah Ibu Dr. Ir. Nana Kariadi Tri Martuti, M.Si dari Fakultas MIPA UNNES dengan materi pengelolaan sumber daya alam dan teknologi tepat guna. Garis besar materi narasumber pertama adalah diversifikasi bahan pangan dari bahan baku umbi-umbian serta bahan baku hasil pertambangan. Hal ini sesuai dengan RPJMD Provinsi Jawa Tengah, RKPD Kabupaten Kendal untuk meningkatkan daya saing bangsa dengan medorong potensi unggulan daerah melalui kegiatan wirausaha.

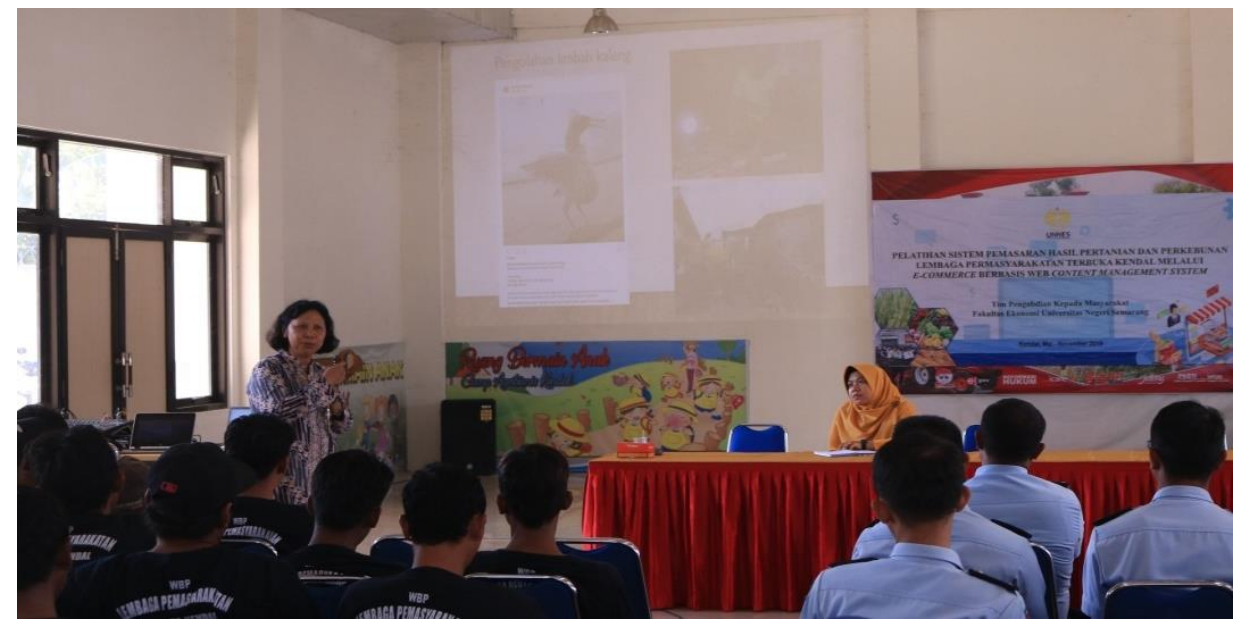

Gambar 3. Paparan Materi Narasumber pertama:

Ibu Dr. Ir. Nana Kariadi Tri Martuti, M.Si

Narasumber kedua adalah Ibu Inaya Sari Melati, S.Pd., M.Pd. (Gambar 4), tentang manajemen keuangan dan investasi untuk menunjang bisnis. Isi materi yang disampaikan meliputi: pengertian literasi keuangan, pentingnya memahami literasi keuangan bagi individu, pengukuran literasi keuangan, manfaat literasi keuangan, aspek literasi keuangan, sumber pendanaan, lembaga keuangan, perencanaan keuangan, manajemen investasi dan keuangan. Dalam paparannya narasumber menyarankan untuk teliti dan cermat dalam mengelola keuangan, sehingga tidak terjadi kesalahan dalam pengalokasian dana.

Setelah paparan materi dari narasumber, untuk memantapkan konsep dan rencana implementasi dari literasi digital, maka peserta diarahkan untuk melakukan focus group discussion (FGD) (Gambar 5). Dari hasil FGD dapat disimpulkan bahwa pada dasarnya lembaga permasyarakatan terbuka kelas IIB Kendal sangat mendukung adanya sosialisasi literasi keuangan, karena di lapas sendiri sudah memiliki sarana dan prasarana yang memadai, akan tetapi masih belum dimanfaatkan secara optimal.

Paparan hasil FGD menyebutkan bahwa belum meratanya tingkat literasi keuangan masyarakat menjadi penyebab belum meratanya tingkat utilitas keuangan. Masyarakat masih memilih menyimpan uang mereka dalam bentuk tunai. Masyarakat di Indonesia dinilai belum begitu memahami produk keuangan seperti bank, asuransi, dan pasar modal. Hal ini disebabkan kurang imbangnya tingkat pertumbuhan industri jasa keuangan dan kesadaran masyarakat terhadap produk keuangan. Di tengah industri keuangan yang berkembang pesat, masih 
banyak masyarakat yang memilih menyimpan uang di rumah. Rendahnya literasi keuangan akan merugikan masyarakat itu sendiri. Masyarakat akan mudah tertipu karena tidak memahami produk keuangan yang terus berkembang.

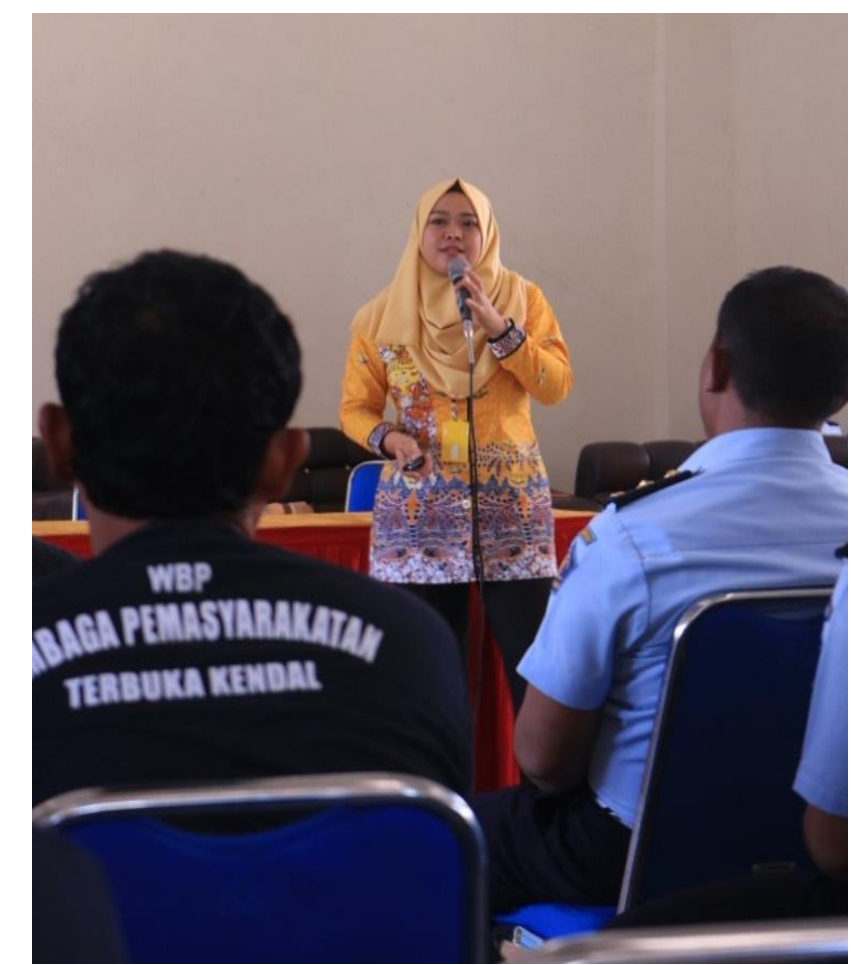

Gambar 4. Paparan materi narasumber kedua: Ibu Inaya Sari Melati, S.Pd., M.Pd

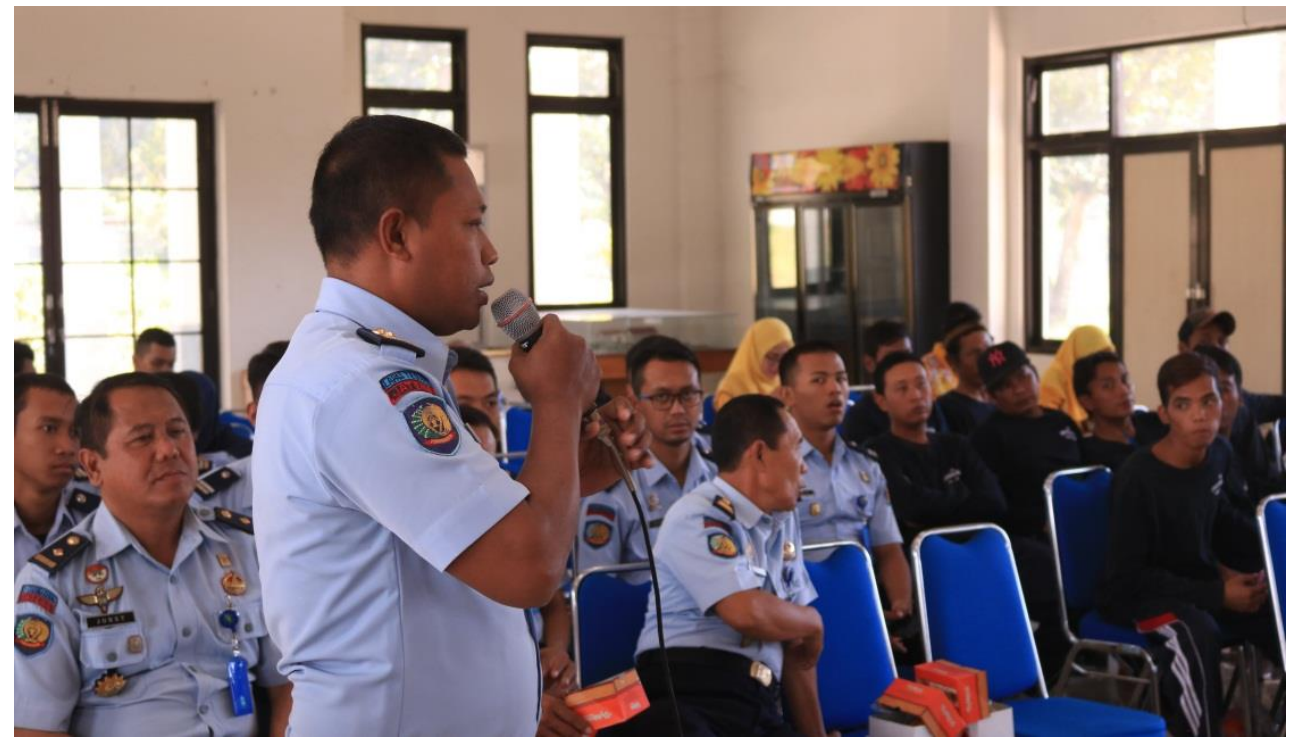

Gambar 5. Diskusi dan Tanya Jawab Workshop

\section{Pendampingan Pasca Workshop}

Program pendampingan pasca workshop adalah implementasi pemahaman literasi keuangan. Menindaklanjuti kegiatan focus group discussion (FGD) dan workshop, tim pengabdi dan pihak lapas melakukan simulasi produk perbankan dilakukan melalui program internet banking. Melalui pembelajaran dengan metode simulasi, diharapkan lebih mendapatkan pengalaman belajar dan lebih memahami 
pentingnya menerapkan literasi keuangan dalam kehidupan sehari-hari. Dari sisi manajemen, tim pengabdi melakukan pendampingan dalam bentuk peningkatan kualitas SDM melalui berbagai motivasi dan strategi pengembangan diri.

Selain implementasi literasi keuangan, berbagai kegiatan yang dilakukan oleh lapas juga aktif diekspos dimedia sosial. Hal ini dilakukan untuk menarik kepercayaan masyarakat terhadap lembaga permasyarakatan dan sebagai media publikasi secara resmi. Alasan utama pemanfaatan media sosial adalah efektivitas menjangkau masyarakat. Berkembangnya media sosial menciptakan 'dunia' baru. Dari media sosial inilah para pengguna saling berinteraksi melalui dunia maya yang tidak bisa dijangkau secara fisik. Lapas produktif Kendal semakin aktif melakukan sosialisasi, sebagai salah satu bentuk pertanggungjawaban kegiatan sebagai lembaga resmi pemerintah. Lapas produktif Kendal menggunakan instagram sebagai media sosial dalam melaporkan setiap kegiatannya, dengan nama akun @lapasterbuka_kendal (Gambar 6).

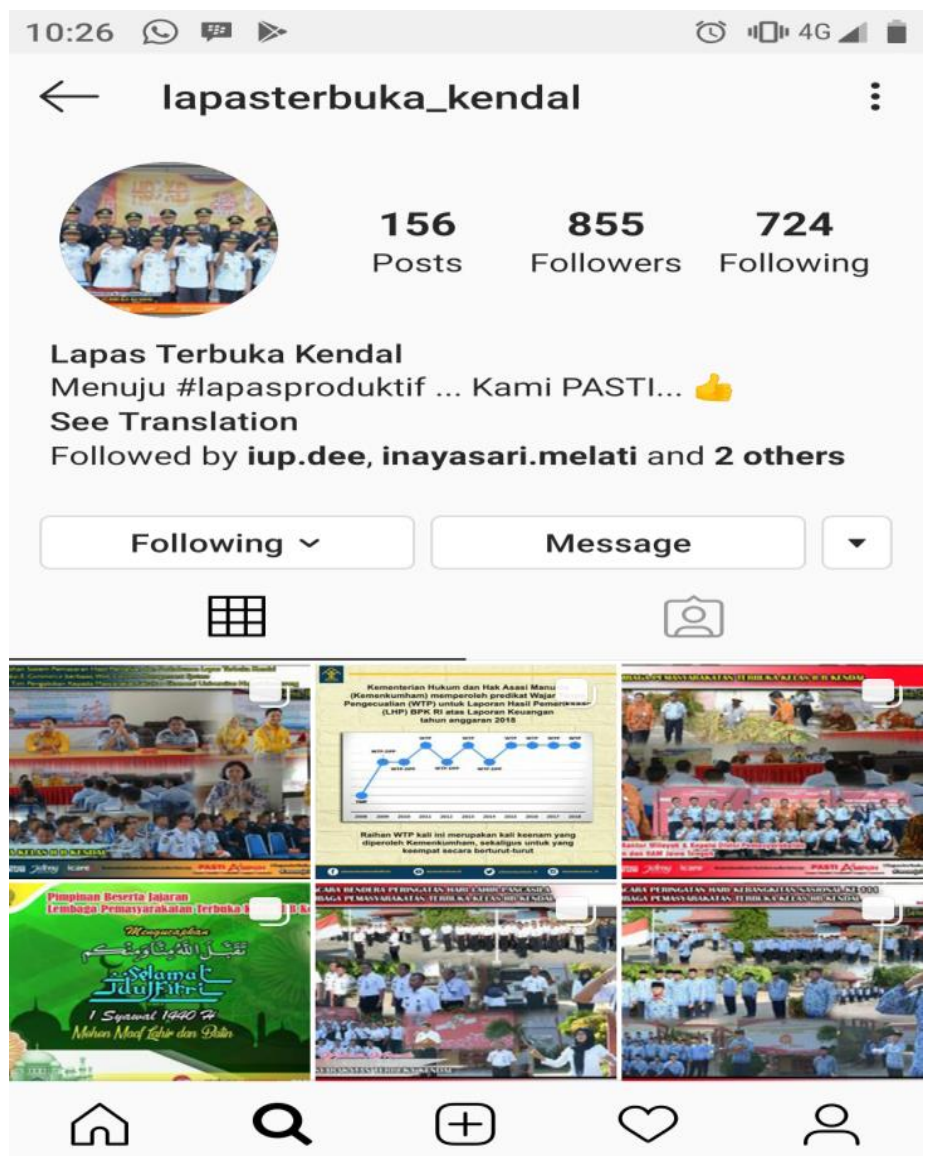

Gambar 6. Instagram Lapas Terbuka Kelas IIB Kendal

Pendampingan selanjutnya adalah memastikan agar implementasi dari literasi keuangan benar-benar berjalan yaitu dengan cara memantau perkembangan pemahamaan pengelolaan keuangan warga binaan. Harapannya akan ada peningkatan kesadaran yang ditunjukkan oleh perubahan perilaku dalam mengelola keuangan. Selain itu juga peningkatan pemahaman produk-produk keuangan yang mendukung bagi pengembangan keuangan dan investasi masyarakat, sehingga akan lebih banyak lagi masyarakat yang semakin rasional dalam pengelolaan keuangan mereka. Semua kegiatan ini dilakukan sebagai bentuk kesepakatan MoA yang telah dilakukan kedua belah pihak, untuk terus mengabdi kepada masyarakat dan meningkatkan literasi masyarakat 


\section{Keberhasilan Kegiatan}

Keberhasilan kegiatan pengabdian kepada masyarakat ini secara garis besar mencakup beberapa komponen yaitu: keberhasilan target jumlah peserta pelatihan, ketercapaian tujuan pelatihan, ketercapaian target materi yang telah direncanakan, kemampuan peserta dalam penguasaan materi. Kemampuan peserta dapat dilihat dari penguasaan materi yang masih kurang karena latar belakang pendidikan peserta dan hanya lulusan SMP/SMA, sehingga hal tersebut menyulitkan mereka untuk memahami beberapa istilah yang berkaitan dengan keuangan. Namun, penggunaan istilah-istilah umum dan beberapa penjelasan mengenai istilah yang kurang mereka pahami telah diberikan oleh narasumber, sehingga peserta dapat memahami isi dari pelatihan dengan baik.

Secara keseluruhan kegiatan pelatihan melek keuangan/ financial literation sederhana bagi warga binaan dan pegawai lapas ini dinilai berhasil. Hal ini dibuktikan dengan keempat komponen diatas dan antusiasme peserta pelatihan. Semua warga binaan dan beberapa pegawai lapas mengikuti kegiatan ini sampai selesai. Hampir semua peserta menginginkan adanya pelatihan literasi keuangan yang lebih detail lagi karena memang pengetahuan mereka mengenai keuangan sangatlah minim. Selain itu manfaat yang mereka dapatkan dari kegiatan ini sangat berguna bagi bekal mereka dalam pengelolaan keuangan dan hubungan dalam dunia usaha kelak.

Berdasarkan hasil wawancara dan laporan dari kepala bidang pembinaan Lapas Terbuka kelas IIB Kendal, ada sekitar 28 warga binaan yang sudah mengalami kenaikan pemahaman bagaimana pengelolaan keuangan yang baik. Hal ini ditunjukkan dengan kemampuan warga binaan dalam memahami prioritas kebutuhan serta mengalokasikan uang yang ada. Sisanya sekitar 6 orang masih belum optimal dalam memahami pengelolaan keuangan, dikarenakan usia yang masih muda dan tingkat pendidikan yang rendah, yaitu lulusan SD. Dari semua warga binaan, tidak ada satu orangpun yang mempunyai usaha, sehingga tolok ukur keberhasilan pengelolaan keuangan usaha tidak bisa terlihat. Indikator keberhasilan lain mengenai selektifitas dalam memilih produk keuangan juga mengalami kenaikan. Hal ini dibuktikan dari hasil wawancara, yang menyebutkan bahwa informan mulai bisa membedakan produk-produk keuangan yang memberikan manfaat jangka panjang dan produk-produk keuangan yang bisa merugikan mereka.

Melalui pendidikan literasi keuangan, membantu masyarakat dalam memahami tentang cara mengelola keuangan dan memberikan gambaran akan peluang demi mencapai kehidupan yang lebih baik di masa yang akan datang. Literasi keuangan bermanfaat bagi seseorang dalam membuat keputusan terutama yang berkaitan dengan aktivitas sehari-hari, seperti saat mengambil keputusan untuk menabung atau investasi serta untuk mencapai tujuan yang sudah ditentukan sebelumnya. Ketidak fahaman tentang literasi keuangan akan sangat berpengaruh terhadap kesehatan keuangan seseorang. Hal tersebut terlihat dari penelitian yang dilakukan oleh Chen (1998) yang menemukan bahwa pemuda dengan tingkat pengetahuan akan literasi keuangan yang kurang baik cenderung mempunyai opini yang salah mengenai keuangan dan cenderung untuk melakukan kesalahan dalam pengambilan keputusan keuangan.

Pemberian pendidikan literasi keuangan yang baik dan benar membuat masyarakat mampu menginternalisasi nilai-nilai tentang literasi keuangan sehingga hal tersebut akan sangat berpengaruh ketika mereka keluar dari lembaga permasyarakatan. Mengingat kejahatan transnasional yang memiliki arus perkembangan yang meningkat tajam, dan Indonesia telah menjadi sasaran utama operasional kejahatan transnasional (Arsyad, dkk, 2017). Tantangan kehidupan yang semakin mengglobal menuntut sebuah sistem perekonomian suatu negera 
untuk terkoneksi dengan dunia. Selain itu, perubahan gaya hidup serta tuntutan zaman yang semakin tinggi dan modern membuat seseorang dituntut mampu bersaing dalam sebuah dunia yang nyaris tanpa batas. Perubahan gaya hidup yang diakibatkan oleh peningkatan kelas menengah di beberapa negara menjadikan bekal pengelolaan keuangan menjadi hal yang wajib untuk diberikan.

\section{Kesimpulan}

Telah terjadi peningkatan pemahaman warga binaan dan pegawai lapas tentang pengelolaan keuangan yang baik dan benar. Keberhasilan program pengabdian ini karena ketercapaian target peserta serta ketercapaian tujuan dan materi kegiatan. Masyarakat yang memiliki literasi keuangan yang baik mampu membuat keputusan yang tepat dalam pengelolaan keuangannya guna menghadapi tantangan global yang berbasis kemajuan teknologi.

\section{Ucapan Terima Kasih}

Ucapan terima kasih diberikan kepada Universitas Negeri Semarang yang telah mendanai kegiatan pengabdian kepada masyarakat, serta lembaga permasyakatan terbuka kelas IIB Kendal yang telah bersedia menjadi mitra pengabdian.

\section{Referensi}

Arsyad, Badu, M.N., Basir, M., Masrie, A., Muchtar, S.M., \& Sultan (2017). Identifikasi dan Pemahaman Dampak Jenis-Jenis Kejahatan Trans Nasional Bagi Siswa SMA Di Kota Makassar. Jurnal Panrita Abdi, 1(1), 47-53.

Bull, R., Cooke, R., Hatcher, R., Woodhams, J., Biby, C., \& Grant, T. (2006). Criminal Psychology. England: Oneworld.

Chen, H. dan R. P. V. (1998). An Analysis Of Personal Financial Literacy Among College Students. Financial Services Review, 7(2), 107-128.

Chinen, K. \& Endo, E. (2012). Effect of Attitude and Bacground on Personal Finance Ability: A Student Survey in the United State. International Journal of Management, 29 (1), 33-45.

Hilgert, M.A. \& Hogarth, J.M. (2003). Household Financial Management: The Connection between Knowledge and Behavior. Federal Reserve Bulletin.

Kartono, K. (2011). Patologi sosial. Jakarta: Rajawali.

Khrisna, A., Rofaida, R,. \& Sari, M. (2010). Analisis Tingkat Literasi Keuangan di Kalangan Mahsiswa dan Faktor-Faktor yang Mempengaruhinya. Proceedings of The 4th International Conference on Teacher Education: Joint Conference UPI \&UPSI.

Laily, N. (2016). Pengaruh literasi keuangan terhadap perilaku mahasiswa dalam mengelola keuangan. Journal of Accounting and Business Education, 1(4).

Lusardi, A, Mitchell, O. S., \& Curto, V. (2010). Financial Literacy Among the Young. Journal of Consumer Affairs, 44(2), pp 358-380.

Margaretha, F., \& Pambudhi, R. A. (2015). Tingkat literasi keuangan pada mahasiswa S-1 fakultas ekonomi. Jurnal Manajemen Dan Kewirausahaan, 17(1), 76-85.

Sholichatun, Y. (2011). Stres dan Strategi Coping pada Anak Didik di Lembaga Pemasyarakatan Anak. Jurnal Psikologi Islam, 8(1), 23-42.

Tomášková, H., Mohelská, H., \& Němcová, Z. (2011). Issues of Financial Literacy Education. Procedia - Social and Behavioral Sciences, 28(0), 365-369. http://doi.org/http://dx.doi.org/10.1016/j.sbspro.2011.11.069

Undang-Undang Republik Indonesia No.12 Th.1995 tentang Pemasyarakatan.

Widayati, I. (2012). Faktor-Faktor yang Mempengaruhi Literasi Finansial 
Mahasiswa Fakultas Ekonomi dan Bisnis Universitas Brawijaya. ASSET: Jurnal Akuntansi Dan Pendidikan, 1(1), 89-99.

Penulis:

Nina Farliana, Jurusan Pendidkan Ekonomi, Fakultas Ekonomi, Universitas Negeri Semarang, Semarang. E-mail: ninafarliana@mail.unnes.ac.id

Khasan Setiaji, Jurusan Pendidkan Ekonomi, Fakultas Ekonomi, Universitas Negeri Semarang, Semarang. E-mail: setiaji@,mail.unnes.ac.id

Indri Murniawaty, Jurusan Pendidkan Ekonomi, Fakultas Ekonomi, Universitas Negeri Semarang, Semarang. E-mail: indrimurniawaty@mail.unnes.ac.id

Hanif Hardianto, Program Pascasarjana Magister Ilmu Hukum, Universitas Diponegoro, Semarang. Email: hanifhardianto@students.undip.ac.id

Bagaimana men-sitasi artikel ini:

Farliana, N., Setiaji, K., Murniawaty, I., \& Hardianto, H. (2020). Optimalisasi Pemberdayaan Narapidana Lembaga Permasyarakatan Terbuka Melalui Literasi Keuangan. Jurnal Panrita Abdi, $4(1), 11-23$ 